\author{
GRAŻYNA WĘGRZYN \\ Uniwersytet Ekonomiczny we Wrocławiu, Polska \\ Wrocław University of Economics, Wrocław, Poland
}

\title{
Kształcenie osób dorosłych jako czynnik zwiększania poziomu innowacyjności krajów Unii Europejskiej
}

\section{Adult Education as a Factor Increasing the Innovativeness of European Union Countries}

\begin{abstract}
Streszczenie: Koncepcja gospodarki opartej na wiedzy zakłada, że głównym czynnikiem rozwoju społeczno-gospodarczego i kształtowania się nowych struktur gospodarki jest wiedza. Jest ona niezbędna do generowania i wdrażania szeroko pojętych innowacji. Wiedza zdobyta w wyniku edukacji formalnej szybko się dezaktualizuje lub jest niewystarczająca, stąd powstaje konieczność ciągłego uczenia się. Edukacja dorosłych obejmuje wszelkie formy uczenia się, które są podejmowane po zakończeniu wstępnego kształcenia i szkolenia. Jest realizowana w trzech formach: formalnej, pozaformalnej i nieformalnej. Celem opracowania jest zweryfikowanie, czy upowszechnianie się kształcenia osób dorosłych w krajach Unii Europejskiej znajduje odzwierciedlenie w zmianach poziomu innowacyjności. Do realizacji celu opracowania wykorzystano krytyczny przegląd literatury, analizę zastanych danych statystycznych oraz analizę porównawczą. Edukacja pozaformalna i nieformalna dorosłych w postaci szkoleń i kursów, które prowadzą do uzyskania kwalifikacji uznawanych wewnątrz danej instytucji (zakładu pracy, organizacji itp.), stanowi ważny czynnik determinujący poziom innowacyjności gospodarki. Kraje, w których w kształcenie przez całe życie są zaangażowane znaczne zasoby siły roboczej, osiągają lepsze wyniki w poziomie innowacyjności niż kraje, w których ten obszar aktywności edukacyjnej jest niedoceniany.
\end{abstract}

\begin{abstract}
The concept of a knowledge-based economy assumes that knowledge is the main factor of socio-economic development and the formation of new economic structures. Knowledge is necessary to generate and implement innovations in their broad sense. Knowledge acquired as a result of formal education quickly becomes outdated or insufficient, hence the need for continuous learning. Continuing education includes all the forms of learning that are pursued subsequent to the completion of initial education and training. It is implemented in three forms: formal, semi-formal and informal. The aim of the study is to verify whether the growing popularity of continuing education in the EU member countries is reflected by changes in the level of innovation. The methods used to achieve the study goal included critical review of literature, analysis of the existing statistical data and comparative analysis. The continuing semi-formal and informal education implemented in the form of training sessions and courses that lead to obtaining qualifications recognised within the specific institution (workplace, organisation, etc.) is an important factor determining the level of innovation in the economy. Countries where a significant proportion of labour force is involved in lifelong learning achieve a higher level of innovation than those where this aspect of educational activity is undervalued.
\end{abstract}


Słowa kluczowe: innowacyjność; kształcenie dorosłych; kształcenie formalne; kształcenie pozaformalne Keywords: adult education; formal education; innovativeness; non-formal education

Otrzymano: 18 grudnia 2018

Received: 18 December 2018

Zaakceptowano: 3 maja 2019

Accepted: 3 May 2019

\section{Sugerowana cytacja / Suggested citation:}

Węgrzyn, G. (2019). Kształcenie osób dorosłych jako czynnik zwiększania poziomu innowacyjności krajów Unii Europejskiej. Prace Komisji Geografii Przemysłu Polskiego Towarzystwa Geograficznego, 33(2), 18-31. doi: $10.24917 / 20801653.332 .2$

\section{WSTĘP}

Koncepcja gospodarki opartej na wiedzy zakłada, że głównym czynnikiem rozwoju społeczno-gospodarczego i kształtowania się nowych struktur gospodarki jest wiedza. Jest ona niezbędna do generowania i wdrażania szeroko pojętych innowacji, zarówno technologicznych, jak i organizacyjnych. Znaczenie poziomu wykształcenia pracowników dla wzrostu i rozwoju gospodarczego było wielokrotnie podkreślane w literaturze (Narasaiah, 2007; Tudor, 2013). Najczęściej wskazywano, że to potencjał endogeniczny w postaci wiedzy, umiejętności i wykształcenia decyduje o rozwoju gospodarek (Fuente, Ciccone, 2003; Lee, Florida, Acs, 2004). Z badań nad zróżnicowaniem gospodarek pod względem poziomu innowacyjności wynika, że innowacje świadczą o potencjale endogenicznym danej gospodarki, a zwłaszcza o jakości jej kapitału ludzkiego i społecznego. Podkreśla się, że rozbieżności w produktywności i wzroście gospodarczym poszczególnych gospodarek nie wynikają z ograniczonego dostępu do zasobów naturalnych, ale ze zdolności do poprawy jakości kapitału ludzkiego i czynników produkcji: zdolności tworzenia nowej wiedzy i pomysłów oraz ich stosowania w praktyce pod postacią innowacji (Ujwary-Gil, 2004). Można więc uznać, że obecnie to luka wiedzy stanowi barierę $\mathrm{w}$ budowaniu przewagi konkurencyjnej oraz zagraża dynamice rozwoju społeczno-gospodarczego (Węgrzyn, 2011).

Ze względów społecznych i ekonomicznych współczesne gospodarki potrzebują pobudzania zdolności kreatywnych i innowacyjnych, aby skutecznie reagować na rozwój społeczeństwa opartego na wiedzy: innowacyjność wiąże się ściśle z kreatywnością rozumianą jako cecha indywidualna i aby w pełni ją wykorzystać, musi być ona szeroko rozpowszechniana wśród ludzi. Wymaga to podejścia opartego na uczeniu się przez całe życie (Decyzja..., 2009).

W epoce społeczeństwa wiedzy ludzie mają do czynienia z powszechnym przepływem informacji, a to wymusza konieczność ciągłego uczenia się. Oznacza to, że wykształcenie i ciągłe podnoszenie kwalifikacji należy traktować jako szczególnie ważne czynniki i generatory nowoczesnego rozwoju. Kraje, w których w kształcenie przez całe życie są zaangażowane znaczne zasoby siły roboczej, osiągają lepsze wyniki w poziomie innowacyjności niż kraje, w których ten obszar aktywności edukacyjnej jest niedoceniany.

W opracowaniu sformułowano następującą hipotezę badawczą: kształcenie dorosłych jest ważnym czynnikiem zwiększającym poziom innowacyjności gospodarki.

Celem opracowania jest zweryfikowanie, czy upowszechnianie się kształcenia osób dorosłych w krajach Unii Europejskiej znajduje odzwierciedlenie w zwiększaniu 
poziomu innowacyjności. Poziomu innowacyjności gospodarek nie da się wyjaśnić jedynie przez udział osób z wyższym wykształceniem wśród ogółu pracujących. To inwestycje w kapitał ludzki osób dorosłych odgrywają szczególną rolę w podnoszeniu poziomu innowacyjności. W opracowaniu postawiono tezę, że wzrost udziału osób dorosłych w kształceniu, tj. zdobywaniu nowej, aktualnej wiedzy, sprzyja innowacyjności gospodarki. Do realizacji celu opracowania wykorzystano krytyczny przegląd literatury, analizę zastanych danych statystycznych oraz analizę porównawczą. W opracowaniu skorzystano z danych statystycznych z dwóch badań koordynowanych przez Eurostat, tj. Badanie aktywności ekonomicznej ludności UE (European Union Labour Force Survey - EU LFS) oraz Kształcenie dorosłych (Adult Education Survey - AES). W analizie uwzględniono osoby dorosłe w wieku 25-64 lata.

Opracowanie składa się z trzech części. W pierwszej wyjaśniono istotę kształcenia dorosłych oraz scharakteryzowano występujące formy edukacji dorosłych, tj. formalną, pozaformalną i nieformalne uczenie się. W części drugiej przeprowadzono analizę porównawczą udziału osób z wyższym wykształceniem formalnym w ogólnej liczbie ludności oraz innowacyjności gospodarek Unii Europejskiej. Część trzecia zwiera analizę danych z zakresu edukacji dorosłych z podziałem na edukację formalną, pozaformalną i nieformalną.

\section{EDUKACJA OSÓB DOROSŁYCH: FORMALNA, POZAFORMALNA I NIEFORMALNA}

Komisja Europejska definiuje kształcenie przez całe życie (Life Long Learning - LLL) jako „wszelkie działania związane z uczeniem się przez całe życie, zmierzające do poprawy poziomu wiedzy, umiejętności i kompetencji w perspektywie osobistej, obywatelskiej, społecznej i/lub związanej z zatrudnieniem" (Making..., 2001). Realizacja idei kształcenia przez całe życie stanowi istotne rozszerzenie zasady kształcenia ustawicznego i powoduje, że obywatele nieustannie gromadzą wiedzę, umiejętności i kompetencje (Dziechciarz, 2015).

Edukacja dorosłych w badaniach Eurostatu dotyczy osób w wieku 25-64 lata, które mają wykształcenie uprawniające do wejścia na rynek pracy, niezależnie od tego, jak długo trwała nauka, łącznie z kształceniem wyższym. Obejmuje wszelkie formy uczenia się podejmowane po zakończeniu wstępnego kształcenia i szkolenia. Edukacja dorosłych jest realizowana w trzech głównych formach (International..., 2012):

- edukacji formalnej (szkolnej) - nauka w systemie szkolnym na poziomie szkoły podstawowej, gimnazjum, zasadniczej szkoły zawodowej, szkoły ponadgimnazjalnej (w tym szkoły policealnej), jak również kształcenie na poziomie studiów wyższych, podyplomowych i doktoranckich. Związana jest z regularną formą nauki realizowanej ściśle w oparciu o przyjęty program kształcenia, kończącej się uzyskaniem kwalifikacji potwierdzonych świadectwem, zaświadczeniem o ukończeniu szkoły, certyfikatem, dyplomem. Cechą wyróżniającą jest to, że jest zorganizowana przez profesjonalnych nauczycieli, istnieje określony program nauczania i często prowadzi do kwalifikacji (Foley, 2004),

- edukacji nieformalnej (nauki przez praktykę, samokształcenie), która ma miejsce poza głównym systemem edukacyjnym, jest procesem niezinstytucjonalizowanym, zamierzonym (samodzielne uczenie się) i niezamierzonym (zachodzącym bezwiednie przez całe życie, najintensywniej na etapie wczesnego rozwoju), 
- edukacji pozaformalnej (incydentalnej) - to proces zinstytucjonalizowany, jednak zachodzący poza formalnym systemem kwalifikacji, który prowadzi do uzyskania kwalifikacji uznawanych wewnątrz danej instytucji (zakładu pracy, organizacji itp.) lub przez część innych instytucji, np. jako dodatkowe kryterium rekrutacji (Kształcenie..., 2009), ale nie powoduje zmiany w poziomie wykształcenia; prowadzi zazwyczaj do rozwoju, poszerzania i zdobywania umiejętności w różnych dziedzinach życia zawodowego, społecznego i kulturalnego; obejmuje wszelkiego rodzaju rozmowy, spotkania towarzyskie, które poprzez wymianę informacji dostarczają wiedzy, kształtują myślenie o świecie. Wyróżnia się następujące formy kształcenia pozaformalnego: kursy, warsztaty i seminaria, nadzorowane szkolenia w miejscu pracy oraz prywatne lekcje.

Jednym z najważniejszych źródeł informacji o edukacji dorosłych jest międzynarodowe badanie Kształcenie dorosłych (Adult Education Survey - AES). Głównym celem badania jest dostarczenie porównywalnych dla krajów Unii Europejskiej danych dotyczących edukacji osób dorosłych. Badanie służy do monitorowania szczegółowych celów programu „Uczenie się przez całe życie” zajmującego znaczącą pozycję w europejskich strategiach rozwoju społeczno-gospodarczego. Dotychczas odbyły się trzy tury organizowanego co pięć lat badania $(2007,2011,2016)$. Dotyczy ono uczestnictwa respondentów w kształceniu formalnym, pozaformalnym i nieformalnym w ciągu ostatnich 12 miesięcy. Drugim źródłem danych na temat kształcenia dorosłych jest badanie European Union Labour Force Survey (EU LFS), w którym pomiar uczestnictwa osób w kształceniu dotyczy ostatnich czterech tygodni przed badaniem. W Polsce realizuje je GUS pod nazwą Badanie aktywności ekonomicznej ludności UE.

\section{ZRÓŻNICOWANIE GOSPODAREK POD WZGLĘDEM FORMALNEGO WYŻSZEGO WYKSZTAŁCENIA I POZIOMU INNOWACYJNOŚCI}

Osiągnięcia edukacyjne dorosłej populacji często traktowane są jako wskaźnik wiedzy i umiejętności dostępnych w gospodarce. Wskaźnik ten przedstawia formalny poziom wykształcenia zdobywanego przez osoby dorosłe. Edukacja tradycyjnie, a w gospodarkach opartych na wiedzy szczególnie edukacja wyższa, uważana jest za główny czynnik odpowiadający za innowacje. Wskazuje się, że jakość krajowych i regionalnych systemów innowacyjnych w dużym stopniu zależy właśnie od poziomu wykształcenia społeczeństwa (Borowiec, Dorocki, Jenner, 2009). Wyższy poziom wykształcenia pracowników generuje większą liczbę innowacyjnych pomysłów, co powoduje wzrost poziomu innowacyjności (Węgrzyn, 2015).

Wiedza zatrudnionych w gospodarce pracowników to potencjał innowacyjny, na który silny wpływ mają jakość i rodzaj formalnego wykształcenia. Do dokonywania międzynarodowych porównań poziomów edukacji najczęściej stosuje się Międzynarodową Standardową Klasyfikację Edukacji - ISCED (International Standard Classification of Education). Obecna wersja ISCED 2011 zastąpiła wcześniejszą, tj. ISCED 97. W opracowaniu poddano analizie dane osób z wyższym wykształceniem, czyli szkolnictwo wyższe (ISCED 5-8) wymagające ukończenia odpowiedniej szkoły szczebla ponadpodstawowego i obejmujące m.in. edukację na poziomie uniwersyteckim, studia podyplomowe i doktoranckie.

W Unii Europejskiej poziom wykształcenia obywateli sukcesywnie wzrasta (rycina 1). W 2006 roku osoby z wyższym wykształceniem stanowiły 20\%, a w 2017 roku 
Rycina 1. Udział osób z wyższym wykształceniem (ISCED 5-8) w krajach Unii Europejskiej w roku 2006 i 2017 (w \% ogółu ludności w wieku 15-64 lata)
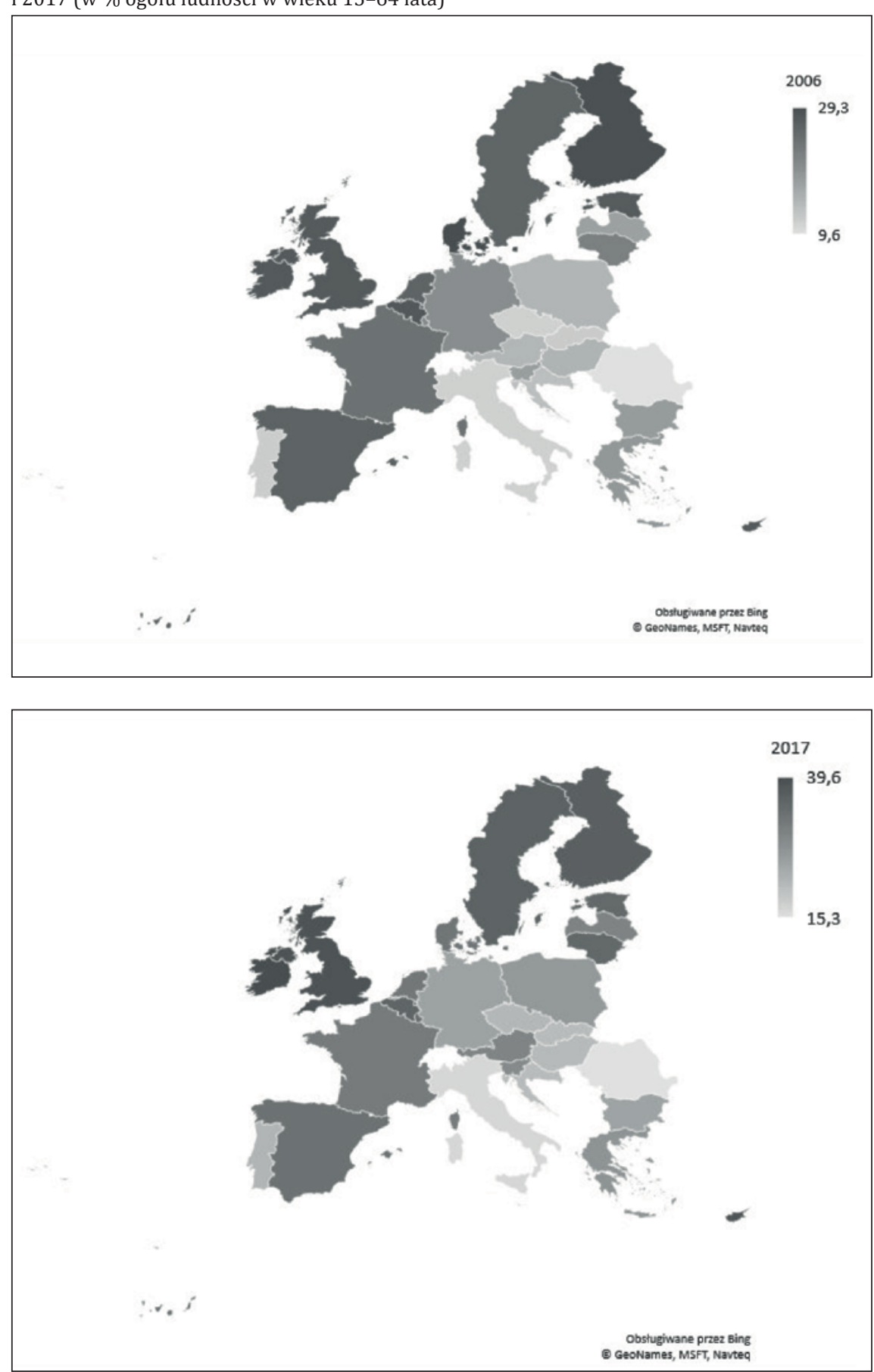

Źródło: opracowanie własne na podstawie danych Eurostatu 
28,8\% ogółu ludności w wieku 15-64 lat. Najniższy odsetek osób z wyższym wykształceniem występuje w Rumunii (9,6\% w 2006 roku, 15,3\% w 2017 roku) i we Włoszech (11,4\% w 2006 roku i 16,5\% w 2017 roku). Z kolei najwyższym - powyżej 35\% udziałem osób z wyższym wykształceniem w 2017 roku charakteryzowały się Irlandia (39,6\%), Wielka Brytania (38,8\%), Cypr (38,1\%), Finlandia (36,4\%), Szwecja $(36, \%)$ oraz Belgia (35,6\%). W latach 2006-2017 najwyższy wzrost udziału osób z wyższym wykształceniem wystąpił w Austrii (15 p.p.), a najniższy we Włoszech (5,1 p.p.) i Rumunii $(5,7$ p.p.). Pomimo wzrostu udziału osób z wyższym wykształceniem w krajach Unii Europejskiej powiększa się różnica między najniższym a najwyższym poziomem tego wskaźnika. W 2006 roku różnica wynosiła 19,7 p.p., a w 2017 roku wzrosła do 24,3 p.p.

W Polsce w badanym okresie nastąpił wzrost udziału osób z wyższym wykształceniem z 14,9\% w 2006 roku do 26,3\% ogółu ludności w wieku 15-64 lata w 2017 roku (tj. wzrost o 11,4 p.p.).

Powszechnie zakłada się, że wyższy poziom wykształcenia pracowników generuje większą liczbę innowacyjnych pomysłów, co przekłada się na wyższy poziom innowacyjności. Dostępne metodologie monitorowania poziomu innowacyjności gospodarek Unii Europejskiej funkcjonują w ramach systemu badań zaprojektowanych na potrzeby realizacji strategii Europa 2020. Najczęściej wykorzystywaną metodologią jest unijna tablica wyników innowacyjności (Innovation Union Scoreboard - IUS), opracowana przez Komisję Europejską. IUS stanowi próbę oszacowania osiągnięć innowacyjnych gospodarek europejskich na podstawie syntetycznego wskaźnika innowacji (Summary Innovation Index - SII). W 2017 roku średni wskaźnik SII dla krajów UE (28) wynosił 0,504 .

W oparciu o wskaźnik SII wyodrębnia się cztery grupy krajów Unii Europejskiej: liderów innowacji (innovation leaders), doganiających liderów (innovation followers), umiarkowanych innowatorów (moderate innovators) i skromnych innowatorów (modest innovators). Na podstawie wskaźnika SII w 2017 roku państwa członkowskie Unii Europejskiej zajęły następujące miejsca w ramach wyodrębnionych grup (rycina 2):

- Grupa I - osiągnięcia liderów innowacji (Szwecja, Dania, Finlandia, Holandia, Wielka Brytania, Luksemburg) kształtowały się na znacznie wyższym poziomie niż przeciętne dla UE. Wskaźnik SII przyjmował wartość powyżej 20\% średniego wskaźnika dla krajów UE (28).

- Grupa II - kraje doganiające liderów stanowiły: Niemcy, Belgia, Irlandia, Austria, Francja.

- Grupa III - umiarkowani innowatorzy: Słowenia, Czechy, Portugalia, Malta, Hiszpania, Estonia, Cypr, Włochy, Litwa, Węgry, Grecja, Słowacja, Łotwa, Polska, Chorwacja.

- Grupa IV - skromni innowatorzy chrakteryzujący się wskaźnikiem SII poniżej 50\% średniego wskaźnika dla krajów UE (28). Zaliczono do tej grupy Bułgarię i Rumunię.

Porównując kraje Unii Europejskiej pod względem formalnego poziomu wykształcenia ludności w wieku 15-64 lata oraz poziomu innowacyjności, nasuwa się wniosek, że poziom wykształcenia formalnego nie gwarantuje wysokiego poziomu innowacyjności. Wśród państw Unii Europejskiej można wyodrębnić kraje, w których wysokiemu odsetkowi osób z wyższym wykształceniem towarzyszy wysoki poziom innowacyjności gospodarki (Szwecja, Finlandia, Wielka Brytania), kraje, w których mimo wysokiego odsetka osób z wyższym wykształceniem innowacyjność jest na niskim poziomie (Cypr, 
Rycina 2. Wskaźnik SII w krajach Unii Europejskiej w 2017 roku

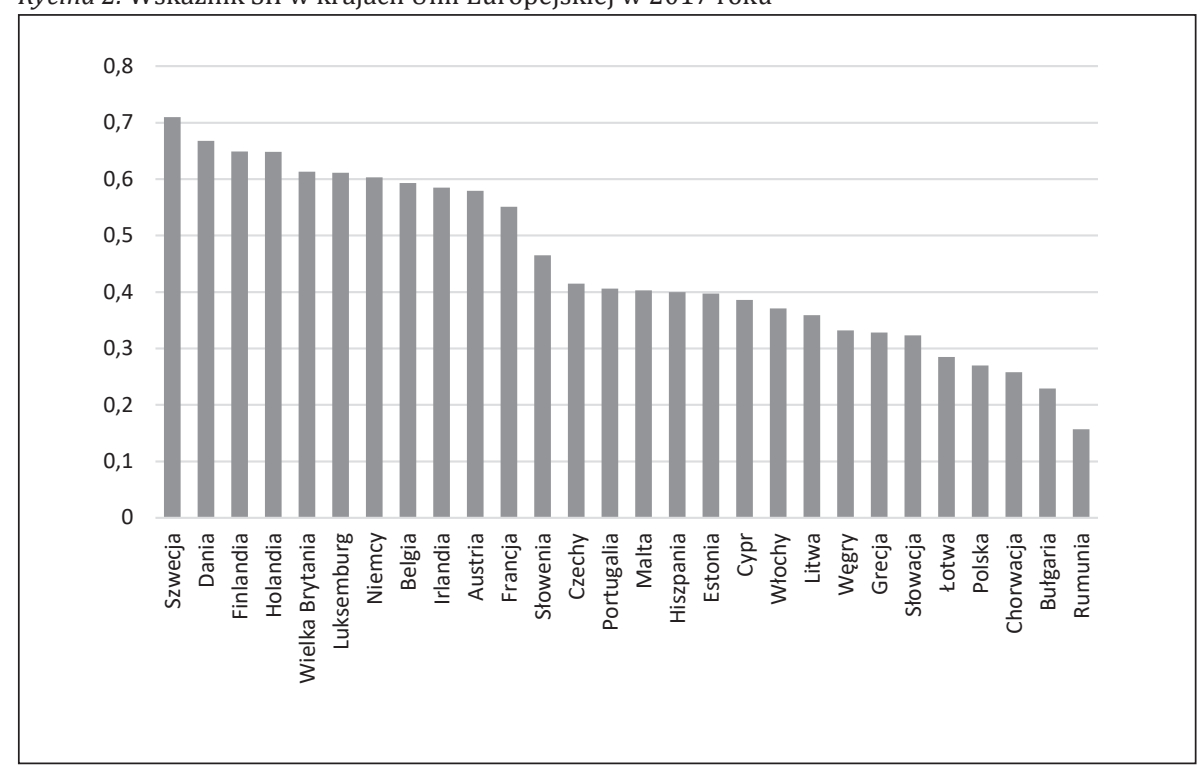

Źródło: opracowanie własne na podstawie European Innovation Scoreboard (2018)

Litwa, Polska) oraz kraje, gdzie pomimo stosunkowo niskiego poziomu wykształcenia formalnego występuje wysoki poziom innowacyjności (Niemcy). Oznacza to, że samo wykształcenie formalne to za mało, aby gospodarka była innowacyjna. Formalne wykształcenie wyższe, zdobyte najczęściej w młodości, w ramach tradycyjnie funkcjonujących szkół wyższych, aktualnie nie wystarcza, by sprostać wyzwaniom szybko zmieniającej się gospodarki opartej na wiedzy. Konieczne jest kształcenie pozaformalne, kierowane do wszystkich, niezależnie od wieku, posiadanych kwalifikacji i umiejętności. Do tego niezbędne jest zapewnienie możliwości stałego rozwijania kompetencji osób dorosłych w sposób elastyczny, oparty na indywidualnym podejściu, w ramach edukacji formalnej, pozaformalnej i nieformalnego uczenia się.

\section{ZRÓŻNICOWANIE GOSPODAREK POD WZGLĘDEM AKTYWNOŚCI EDUKACYJNEJ DOROSŁYCH}

Kształcenie osób dorosłych w poszczególnych krajach Unii Europejskiej, podobnie jak całe systemy edukacyjne, różni się pod wieloma względami. Według danych pochodzących z Badania aktywności ekonomicznej ludności UE (EU LFS) wskaźnik uczestnictwa dorosłych w kształceniu formalnym i pozaformalnym ${ }^{1}$ dla państw Unii Europejskiej (28) w 2017 roku wynosił 10,9\%, a docelowo do 2020 roku powinien wzrosnąc do co najmniej 15\%. W państwach nordyckich oraz Holandii, Estonii, Francji i Luksemburgu już osiągnięto uzgodniony na 2020 rok cel europejski. Natomiast w takich krajach jak Rumunia, Bułgaria i Chorwacja (gdzie w edukacji uczestniczy mniej niż 2,5\% dorosłych), a także w Polsce, Grecji i na Słowacji (gdzie wskaźnik nie przekracza 5\%)

\footnotetext{
${ }^{1}$ Wskaźnik uczestnictwa w kształceniu i szkoleniach obejmuje osoby w wieku 25-64 lata uczestniczące w formalnej i nieformalnej edukacji i szkoleniach. Okres referencyjny dla uczestnictwa w kształceniu i szkoleniach to cztery tygodnie przed badaniem.
} 
poziom udziału dorosłych w kształceniu i szkoleniach jest znacznie odleglejszy od przyjętego celu (tabela 1).

Tabela 1. Osoby w wieku 25-64 lata uczestniczące w kształceniu formalnym i pozaformalnym (w okresie czterech tygodni poprzedzających badanie) w krajach Unii Europejskiej w 2017 roku (w \%)

\begin{tabular}{|c|c|c|c|c|}
\hline Kraje & $\begin{array}{c}\text { Osoby } \\
\text { uczestniczące } \\
\text { ogółem }\end{array}$ & $\begin{array}{c}\text { Kobiety } \\
\text { uczestniczące }\end{array}$ & $\begin{array}{l}\text { Osoby pracujące } \\
\text { uczestniczące }\end{array}$ & $\begin{array}{c}\text { Osoby z wyższym } \\
\text { wykształceniem } \\
\text { uczestniczące }\end{array}$ \\
\hline UE (28) & 10,9 & 11,8 & 11,6 & 18,6 \\
\hline Belgia & 8,5 & 8,8 & 8,6 & 13,7 \\
\hline Austria & 15,8 & 17,3 & 16,4 & 26,6 \\
\hline Bułgaria & 2,3 & 2,4 & 1,6 & 4,1 \\
\hline Chorwacja & 2,3 & 2,6 & 1,8 & 4,5 \\
\hline Cypr & 6,9 & 7,1 & 7,1 & 11,4 \\
\hline Czechy & 9,8 & 10,0 & 10,7 & 17,6 \\
\hline Dania & 26,8 & 31,4 & 27,3 & 33,9 \\
\hline Estonia & 17,2 & 20,6 & 18,6 & 26,1 \\
\hline Finlandia & 27,4 & 31,5 & 28,9 & 35,0 \\
\hline Francja & 18,7 & 21,1 & 20,7 & 29,8 \\
\hline Grecja & 4,5 & 4,4 & 4,4 & 7,7 \\
\hline Hiszpania & 9,9 & 10,6 & 9,8 & 16,7 \\
\hline Holandia & 19,1 & 20,1 & 20,7 & 26,2 \\
\hline Irlandia & 8,9 & 9,9 & 8,3 & 12,7 \\
\hline Litwa & 5,9 & 7,3 & 6,5 & 10,0 \\
\hline Luksemburg & 17,2 & 17,6 & 19,1 & 25,6 \\
\hline Łotwa & 7,5 & 8,8 & 8,0 & 11,5 \\
\hline Malta & 10,6 & 11,9 & 12,4 & 20,9 \\
\hline Niemcy & 8,4 & 8,1 & 7,9 & 12,5 \\
\hline Polska & 4,0 & 4,4 & 4,5 & 8,6 \\
\hline Portugalia & 9,8 & 10,0 & 9,9 & 20,4 \\
\hline Rumunia & 1,1 & 1,0 & 0,9 & 2,7 \\
\hline Słowacja & 3,4 & 3,3 & 3,6 & 6,7 \\
\hline Słowenia & 12,0 & 14,1 & 13,3 & 21,4 \\
\hline Szwecja & 30,4 & 37,5 & 29,3 & 39,2 \\
\hline Węgry & 6,2 & 6,4 & 7,0 & 11,5 \\
\hline Wielka Brytania & 14,3 & 15,8 & 15,7 & 20,1 \\
\hline Włochy & 7,9 & 8,4 & 8,5 & 18,3 \\
\hline
\end{tabular}

Źródło: opracowanie własne na podstawie danych Eurostatu

Cechami różnicującymi uczestnictwo dorosłych w edukacji w poszczególnych krajach są głównie płeć, aktywność zawodowa oraz poziom wykształcenia. W większości państw Unii Europejskiej wskaźniki uczestnictwa w kształceniu były wyższe dla kobiet niż dla mężczyzn. Jedynie w czterech krajach, w Niemczech, Grecji, Słowacji i Rumunii, odsetek mężczyzn biorących udział w kształceniu był nieznacznie wyższy niż kobiet.

Najwyższy odsetek pracujących dorosłych uczestniczących w kształceniu formalnym i pozaformalnym wystąpił w Szwecji (29,3\%), Finlandii (28,6\%), Danii (27,3\%), Francji i Holandii (po 20,7\%). Najniższy natomiast w Rumunii $(0,9 \%)$, Bułgarii $(1,6 \%)$ 
i Chorwacji $(1,8 \%)$. We wszystkich państwach Unii Europejskiej wśród dorosłych uczestniczących w kształceniu formalnym i pozaformalnym największy odsetek stanowiły osoby z wykształceniem wyższym. Najwyższym odsetkiem dorosłych z wyższym wykształceniem uczestniczących w kształceniu formalnym i pozaformalnym charakteryzowały się Szwecja (39,2\%), Finlandia $(35,0 \%)$ oraz Francja $(29,8 \%)$, a najniższym Rumunia (2,7\%).

Dane na temat kształcenia dorosłych pochodzące z Badania aktywności ekonomicznej ludności UE warto uzupełnić wynikami badania przygotowanego specjalnie z myślą o ocenie udziału dorosłych w kształceniu i szkoleniu, tj. badania Kształcenie dorosłych (AES, 2009). Badanie dostarcza szczegółowych informacji dotyczących działań i programów edukacyjnych, w których biorą udział osoby dorosłe. Respondenci odpowiadali na pytanie, czy w ciągu 12 miesięcy poprzedzających badanie sami poszukiwali możliwości uczenia się lub czy kierowane były do nich informacje na ten temat. Z porównania danych z trzech przeprowadzonych dotychczas w krajach UE badań $(2007,2011$, 2016) wynika, że aktywność edukacyjna dorosłych systematycznie wzrasta. W Unii Europejskiej udział procentowy osób w wieku 25-64 lata, które podjęły jakąkolwiek formę kształcenia, wzrósł z 35,2\% w 2007 roku do 40,3\% w 2011 roku, a następnie w roku 2016 zwiększył się do 45,1\%. W poszczególnych państwach europejskich występują jednak znaczne różnice. Najwyższe wskaźniki w zakresie udziału dorosłych w kształceniu w 2016 roku wystąpiły w Holandii (64,1\%), Szwecji (63,8\%) i Austrii (59,9\%). Najniższe w Rumunii $(7,0 \%)$, Grecji $(16,7 \%)$, Bułgarii $(24,6 \%)$ i w Polsce $(25,5 \%)$ (rycina 3).

Przy porównaniu wyników Badania aktywności ekonomicznej ludności UE (EU LFS) z wynikami badania Kształcenie dorosłych (AES) widać bardzo wyraźne różnice. Według danych z tego pierwszego badania zaledwie 10,9\% dorosłych uczestniczy w kształceniu, podczas gdy wyniki AES wskazują, że około 45\% dorosłych mieszkańców Unii Europejskiej jest objętych edukacją formalną i pozaformalną. Różnice te częściowo mają związek z faktem, że w badaniu EU LFS punkt odniesienia to zaledwie cztery tygodnie przed przeprowadzeniem badania, podczas gdy w przypadku AES okres ten wynosi 12 miesięcy. Oznacza to, że osoby dorosłe, które nie uczestniczyły w edukacji w okresie ostatnich czterech tygodni poprzedzających badanie EU LFS (a zatem uznawane za osoby nieuczące się), mogły brać udział w kształceniu w dłuższym przedziale czasowym (Dorośli.., 2011). Dodatkowo osoby dorosłe najczęściej biorą udział w kształceniu pozaformalnym, które charakteryzuje się krótkim czasem trwania (Rosenbladt, 2009).

Wyniki Badania aktywności ekonomicznej ludności UE oraz badania Kształcenie dorosłych pokazują, że odsetek uczestniczących w kształceniu formalnym jest znacznie niższy niż w kształceniu pozaformalnym. Zgodnie z danymi z AES średni poziom udziału dorosłych w formalnym systemie edukacji i szkoleń wynosi w Unii Europejskiej 5,8\% i w porównaniu z wynikami z 2007 roku obniżył się o 0,8 p.p. Wyraźnie natomiast zwiększył się odsetek dorosłych biorących udział w kształceniu pozaformalnym. W 2006 roku w UE w kształceniu pozaformalnym uczestniczyło 31,6\% osób, natomiast w 2016 roku udział ten wzrósł do 42,6\% ogółu dorosłych obywateli (wzrost o 11 p.p.). W poszczególnych państwach udział dorosłych w kształceniu pozaformalnym wahał się w 2016 roku od 5,6\% w Rumunii do 61,5\% w Holandii.

Wyniki badania Kształcenie dorosłych w zakresie edukacji osób pracujących, z uwzględnieniem wykonywanego przez nie zawodu, pokazały, że najliczniejszą ogólną grupą zawodową biorącą udział w kształceniu pozaformalnym w Unii Europejskiej są 
Rycina 3. Osoby w wieku 25-64 lata uczestniczące w kształceniu (w okresie 12 miesięcy przed badaniem) w krajach Unii Europejskiej w 2016 roku (w \%)

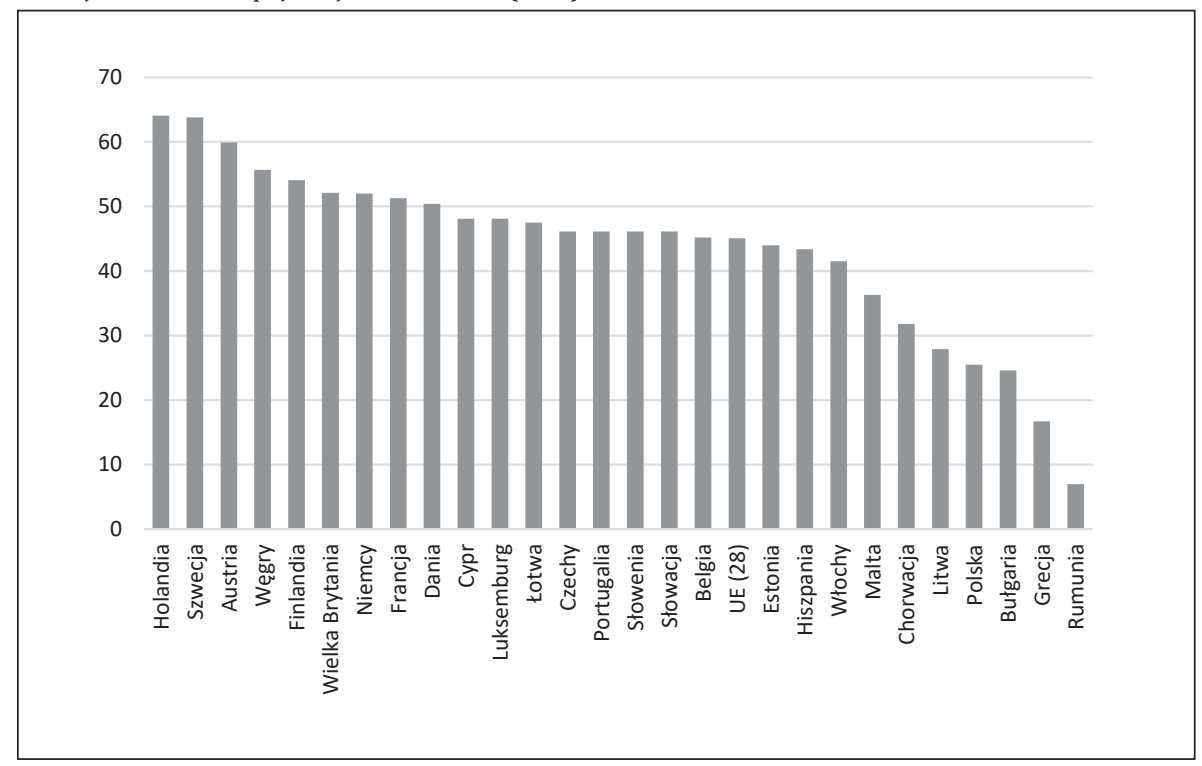

Źródło: opracowanie własne na podstawie danych Eurostatu

różnego rodzaju specjaliści (65,5\%). Przy czym w Holandii i Austrii ponad 80\% specjalistów uczestniczyło w kształceniu pozaformalnym, a w Rumunii było to $14,1 \%$. W Polsce 49,7\% specjalistów deklarowało udział w kształceniu pozaformalnym. Warto podkreślić również, że uczestnictwo w szkoleniach i podejmowanie innych form kształcenia pozaformalnego przez specjalistów w głównej mierze miało związek z wykonywaną pracą $(59,8 \%)$ i najczęściej było finansowane przez pracodawcę $(42,2 \%)$. W poszczególnych krajach sytuacja była zróżnicowana. Najwyższym odsetkiem specjalistów uczestniczących w kształceniu pozaformalnym finansowanym przez pracodawcę charakteryzowały się: Holandia $(73,4 \%)$, Austria $(67,6 \%)$, Szwecja $(67,6 \%)$, Słowenia $(61,8 \%)$, Dania $(61,6 \%)$, Niemcy $(60,6 \%)$ i Finlandia $(60,4 \%)$, a najniższym Rumunia $(9,7 \%)$ i Grecja $(15,1 \%)$.

Na rycinie 4 przedstawiono dane o innowacyjności gospodarek (Summary Innovation Index - SII 2017) oraz osobach w wieku 25-64 lata uczestniczących w kształceniu formalnym i pozaformalnym, gdzie wyraźnie widać znaczącą dodatnią korelację (współczynnik korelacji Pearsona 0,825, p=0,0000).

W krajach będących liderami innowacji średni odsetek osób dorosłych uczestniczących w kształceniu formalnym i pozaformalnym w 2017 roku wynosił 22,5\%, w krajach doganiających liderów - 12,1\%, w krajach będących umiarkowanymi liderami $7,9 \%$, a w krajach zaliczanych do skromnych innowatorów było to zaledwie 1,7\%.

\section{ZAKOŃCZENIE}

Badanie aktywności ekonomicznej ludności UE (LFS EU) oraz badanie Kształcenie dorosłych (AES) realizowane w krajach Unii Europejskiej pokazują, że systematycznie wzrasta udział dorosłych w szeroko rozumianym kształceniu. Przy czym odsetek 
Rycina 4. Osoby w wieku 25-64 lata uczestniczące w kształceniu formalnym i pozaformalnym w 2017 roku (w \%) oraz wskaźnik Summary Innovation Index - SII 2017 w krajach Unii Europejskiej

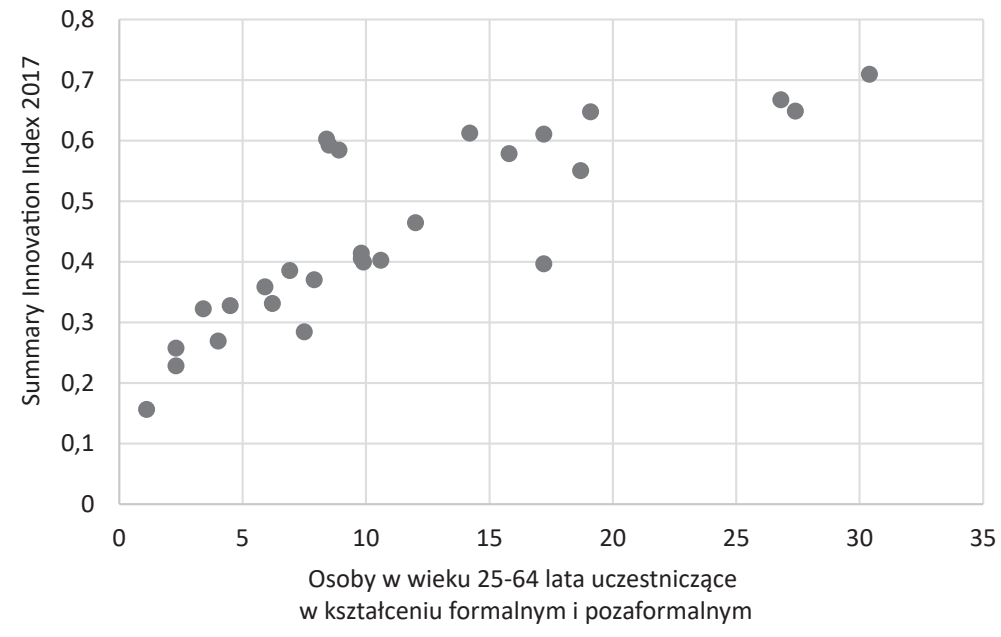

Źródło: opracowanie własne na podstawie danych Eurostatu

dorosłych uczestniczących w kształceniu formalnym jest znacznie niższy niż w kształceniu pozaformalnym. Z przeprowadzonej analizy poziomu uczestnictwa dorosłych w edukacji oraz innowacyjności gospodarek Unii Europejskiej wynika, że kształcenie dorosłych jest niezbędne do budowania nowoczesnej, innowacyjnej gospodarki. Gospodarki zaliczane do liderów innowacji czy doganiających liderów charakteryzują się wysokim odsetkiem osób z wyższym wykształceniem w ogólnej liczbie ludności, ale przede wszystkim wyróżniają się wysokim odsetkiem dorosłych uczestniczących w kształceniu. Zdobywanie aktualnej wiedzy przez osoby dorosłe z wyższym wykształceniem szczególnie poprzez kształcenie pozaformalne zdaje się być ważnym czynnikiem zwiększającym poziom innowacyjności gospodarek. Inicjatywy edukacyjne we wszystkich krajach Unii Europejskiej podejmują przede wszystkim osoby z wykształceniem wyższym, szczególnie osoby zaliczane do grupy zawodowej specjaliści. Dodatkowo gospodarki innowacyjne charakteryzują się wysokim odsetkiem dorosłych uczestniczących w kształceniu pozaformalnym związanym z wykonywaną pracą i finansowanym przez pracodawców.

Dynamiczne zmiany zachodzące w gospodarce wymuszają ciągłe podnoszenie poziomu wiedzy, wykształcenia i umiejętności. Niewystraczające jest zaprzestanie kształcenia po ukończeniu kształcenia formalnego, czyli najczęściej w młodości. Wskazane jest, aby osoby dorosłe, ucząc się przez całe życie, podejmowały aktywności na każdym etapie swojego życia w celu pogłębienia wiedzy oraz uzyskania nowych umiejętności i kompetencji. Umożliwienie aktywnym zawodowo dorosłym uczenia się i zdobywania aktualnej wiedzy jest kluczowym czynnikiem współczesnego rozwoju społecznego i ekonomicznego oraz samorealizacji poszczególnych jednostek. Edukacja dorosłych przynosi korzyści w postaci większych szans zatrudnienia i wyższych kompetencji 
zawodowych, a także większego zaangażowania obywatelskiego oraz lepszego dobrobytu. Dodatkowo zdobywanie nowej wiedzy w dojrzałym wieku zwiększa kreatywność pracowników, co przekłada się na wzrost innowacyjności firmy, a tym samym całej gospodarki.

\section{Literatura \\ References}

Borowiec, M., Dorocki, S., Jenner B. (2009). Wpływ zasobów kapitału ludzkiego na kształtowanie społeczeństwa informacyjnego i innowacyjności struktur przemysłowych. Prace Komisji Geografii Przemysłu Polskiego Towarzystwa Geograficznego, 13, 95-109.

Decyzja Parlamentu Europejskiego i Rady nr 1350/2008/WE z 16 grudnia 2008 r. dotycząca Europejskiego Roku Kreatywności i Innowacji (2009). Dziennik Urzędowy Unii Europejskiej z 24 grudnia 2008 r. Pozyskano z https://eur-lex.europa.eu/legal-content/PL/TXT/ PDF/?uri=CELEX:=154\&from $=$ EN

Dorośli w systemie edukacji formalnej: polityka i praktyka w Europie (2011). Agencja Wykonawcza ds. Edukacji, Kultury i Sektora Audiowizualnego (EACEA). Warszawa: Fundacja Rozwoju Systemu Edukacji.

Dziechciarz, J. (2015). Pomiar i wycena wiedzy, umiejętności i kompetencji nabytych w formalnych i nieformalnych formach kształcenia. W: P. Wdowiński (red.). Nauczyciel akademicki wobec nowych wyzwań edukacyjnych. Łódź: Wydawnictwo Uniwersytetu Łódzkiego.

European Innovation Scoreboard 2018 (2018). Pozyskano z https://www.interregeurope.eu/ policylearning/news/3806/european-innovation-scoreboard-2018/

Foley, A. (2004). Dimensions of Adult Learning. Adult education and training in a global era. Open University Press.

Fuente, de la A., Ciccone, A. (2003). Human Capital in a Global and Knowledge-based Economy. Paris: European Commission.

International Standard Classification of Education ISCED 2011 (2018, 7 listopada). UNESCO Institute for Statistics, Montreal, Canada 2012. Pozyskano z http://uis.unesco.org/sites/default/files/documents/international-standard-classification-of-education-isced-2011-en

Kształcenie dorosłych (2009). Departament Pracy i Warunków Życia. Informacje i opracowania statystyczne. GUS: Warszawa.

Lee, S.Y., Florida, R., Acs, Z. (2004). Creativity and Entrepreneurship: a Regional Analysis of New Form Formation. W: Discussion Papers on Entrepreneurship, Growth and Public Policy. Jena: Max Planck Institute.

Making a European Area of Lifelong Learning a Reality. Komunikat Komisji Europejskiej, COM (2001) 678. Pozyskano z https://eur-lex.europa.eu/LexUriServ/LexUriServ.do?uri=COM:2001:0678:FIN:EN

Narasaiah, M.L. (2007). Education and Economic Development. New Delhi: Discovery Publishing Hause.

Rosenbladt, B. (2009). Adult education and training in comparative perspective - understanding differences across countries. Monachium: TNS Infratest Sozialforschung.

Tudor, S.L. (2013). Formal Non-formal - Informal in Education. Procedia - Social and Behavioral Sciences, 76, 821-826.

Ujwary-Gil, A. (2004). Inwentyka, czyli kreatywność w biznesie. Wybrane zagadnienia. Nowy Sącz: Wyższa Szkoła Biznesu - National-Louis University.

Węgrzyn, G. (2011). Sektor usług - zmiany w zatrudnieniu i innowacyjności. Prace Naukowe Uniwersytetu Ekonomicznego we Wrocławiu, 168(2), 363-376.

Węgrzyn, G. (2015). Wykształcenie i kwalifikacje pracowników jako determinanta zmian w poziomie innowacyjności gospodarek. Ekonomia XXI Wieku, 1(5), 90-100.

Grażyna Węgrzyn, dr hab., prof. nadzw. UE, Uniwersytet Ekonomiczny we Wrocławiu, Katedra Ekonomii i Polityki Ekonomicznej. Zainteresowania badawcze: rynek pracy, innowacyjność, gospodarka oparta na wiedzy, makroekonomia. 
Grażyna Węgrzyn, professor, Wrocław University of Economics, Department of Economics and Economic Policy. Research interests: labour market, innovation, knowledge-based economy, macroeconomics.

ORCID: 0000-0003-4735-2807

\section{Adres/address:}

Uniwersytet Ekonomiczny we Wrocławiu Katedra Ekonomii i Polityki Ekonomicznej ul. Nowowiejska 3, 58-500 Jelenia Góra, Polska

e-mail: grazyna.wegrzyn@ue.wroc.pl 